\title{
原油エマルジョンの破壞に關 する研究（第一報）
}

\section{矢部孟* 上田雷春*}

On the Treatment of Crude Oil Emulsions.

By M. Yabe and S. Ueda

The writers studied the treatment of crude oil emulsions produced in the several oil fields in Japan. In all cases, it is necessary to keep $\mathrm{pH}$ value $7.2-7.8$ to obtain the successful resluts for breaking those emulsions.

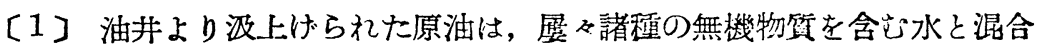
されて居ろが、時に此の油水は可なり安定な油中水滴型エマルジョンを形成 して居る。

此の原油中の水の含量を減らすをぬに，從來から譛䅜の考案が行はれて居 り, 加壓下減壓下に於る加熱, 遠心分離法の如き機械的な方法 ${ }^{1}$ ‘行はれる が，藥品の使用或は電氣的な脫水法

特に此のエマルション破壞劑としては既に幾多の藥品が考案せられ夫及研 究者よりその特徵が報告されて居る。その代表的なものは Gelbke ${ }^{3}$, Limb$v \mathrm{vrg}^{4}$ 及び Liberthon ${ }^{5}$ 等の石油を主原料とするスルフォン酸及びそのカル シウム監，更にそれらと諸種の添加物を用ひる Chambelain ${ }^{6}$, Sereda $^{7}$ 及 び Groote $\mathrm{e}^{8}$ 等の方法も特許されて居る。

メソビェートに於ては精油上酸處理する時のケロシン油より得られる石油

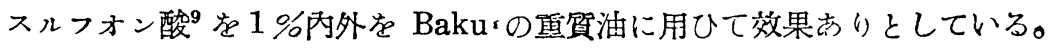
佾此等のエマルジョンは $90^{\circ} \sim 95^{\circ} \mathrm{C}$ 或はそれ以下にて處理されろが，此 の事賽に對しては油に溶解する Ca-Sulphonates から遊離のスルフオン酸と

*帝國石油株式會社技煺研究所 
Ca-Naphthenates の間の交流が起つて。その結果エマルジョンが破壞され るといふ。Fisher ${ }^{10}$ は此等を助ける篇に $\mathrm{C}_{2} \mathrm{H}_{5} \mathrm{OH}$ の少量の添加が w:o 型工 アルションに有效であると發表した。

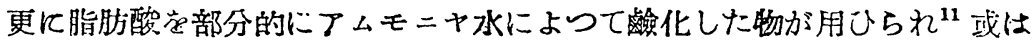
脂肪酸と Naphthenic acid を用ひる事12 が知られた。

その他 $\mathrm{NaOH}^{13}, \mathrm{Na}_{2} \mathrm{CO}_{3}{ }^{14}$ 及びオレイン酸ンーダ15 が此の目的に對して 使用されている。

以上の如く諸種薬品が米國或はソ聯に於て研究され，吾國に於ても北大の 岡本氏 は AIkyl Naphththalane Sulphonic Acid が良しとして居る。

次に此のエマルジョンの最も分離し易き狀態に關しても烧多の研究があ り, Fllis ${ }^{17}$ は「w/o 型エマルジョンは電氣運動電位が最大の點郎占微アル

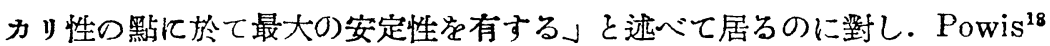
は之に反對して油水界面の電位差が \pm 0.03 volt を超えらと安定であり．等 電點附近では最も不安定であるとの說を持し, 又 Steik $^{19} も$ 界面電位美に對 する電解筫の影響学研究して Powis を支持する如き結思を發表して居る。

筆者らも有效なる破壞劑つ必要伯迫られて研究に着手し吾國原油エアルジ

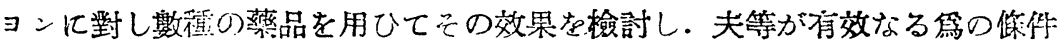
等に多少の見解が得られたので此處に報告する。

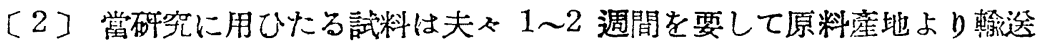
と受けたものであるが，夏季!二於ては輸迼の途上に於て，その含有水の先分 を分離するものが見られた。夫等は小瀧及び高野のエマルジョンであろが， 窒內に靜置することに依り更に遊離水を見る。然して冬季に於ては他地域の エマルジョンは勿論. 此等のエマルジョンに於ても放置に依つては水の分離 は全く見られない。

而るに此等を加熱に依つて 3 時間以上 $50 \sim 70^{\circ} \mathrm{C}$ に保ちたるに小瀧高野の エマルジョンには更に遊蜼水が見られたのであるが，他のエマルジョンに於 てはその效果は殆んぞ檢出し得ない。 


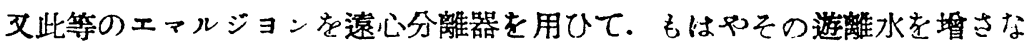
くなる迄，比较的一定の回轉數 (300 r.p.m.) に於て處理して見ると第 1 表 の如き結果が得られた。

第 1 表 各地原油エマルジョンの遭心分離結果

\begin{tabular}{|c|c|c|c|c|c|c|}
\hline 試 & & 科 & 新發田 & 小鹘 & 商 野 & 八 森 \\
\hline 分 & 離 & 時間 & $2 \mathrm{hrs}$ & $2 \mathrm{hrs}$ & $30 \min *$ & $2 \mathrm{hrs}$ \\
\hline \multirow{4}{*}{$\begin{array}{l}\text { 分 } \\
\text { 離 } \\
\text { 結 } \\
\text { 果 }\end{array}$} & \multicolumn{2}{|r|}{ 油 } & $35 \%$ & $50 \%$ & $15 \%$ & $0 \%$ \\
\hline & \multicolumn{2}{|r|}{ エマルジョン } & 20 & 20 & 32.5 & 100 \\
\hline & \multicolumn{2}{|r|}{ 水 } & 40 & 30 & 48.0 & 0 \\
\hline & \multicolumn{2}{|r|}{ 砂 } & 5 & 0 & 5.5 & 0 \\
\hline
\end{tabular}

*30min 以上回轉すれは更に完全に分離する

以上の結果は. エマルジョンの種類により，かくの如き機械的な方法に於 $\tau$

（1）容易に分蜼されるもの（小瀧，高野）

（2）部分的に分蜼されるが，猶一部にはエマルジョンが殘るもの（新磞 田）

（3）蒸溜その他に依つては可なりの水を含むに不拘，かっ己處理では全 く遊離水を見せないもの（八森） の三者のあることを示す。

佁（3）の場合に就ては，エマルジョンの本質が（1），(2) の埸合上異 る如く考へられる。郎ち現在，含有水が或る程度化學的な結合狀態にあるの ではないかと考へられろのであつて，此の事に關しては別に研究をもちたい と思ふ。

從つて以下に於ては主として (1)，（2）の場合に就いて論じて行く

前述の Fisher ${ }^{20}$ は， $\mathrm{C}_{2} \mathrm{H}_{5} \mathrm{OH}$ の少量を用ひてェマルジョンの破壞を促進 せしめろこと在報告して居るが．夫れと同樣の目的で吾くは（1）より小㴰 エマルジョン，（2）より新投田エマル洋ヨンを取つて, 雨者に對し各種の 
有機溶刋在用ひて油水双方或は一方の粘性の減少在圖つて，エマルジョンの

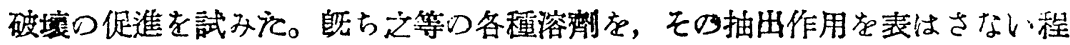
度に少量加一，或は加熱を行つて，添加前後の破壞狀況を比較した。そつ結 果は第2 表でるる。

第2表 有機溶劑に依ろ原油エマルジョン分離狀態

\begin{tabular}{|c|c|c|c|c|c|c|c|}
\hline 試 科 & \multicolumn{4}{|c|}{ 新 發 田 } & \multicolumn{3}{|c|}{ 小 } \\
\hline 添加狱刨 & 渿加量 & 加熱 & 分 離 & 狀態 & |添加量 & 加濯 & 分拉態 \\
\hline $\begin{array}{l}\mathrm{CH}_{3}-\mathrm{CO}- \\
\mathrm{C} \mathrm{I}_{3}\end{array}$ & $1: 2$ & $3 \mathrm{hrs}$ & 脫水効思著 & & $1: 10$ & $4 \mathrm{his}$ & 盼水効了落渚し \\
\hline トルエン & $1: 3$ & & $\begin{array}{l}\text { 24hr 放監 } \\
\text { 至得 }\end{array}$ & ボ30\%の油 & $1: 10$ & $5 \mathrm{hrs}$ & 4O\%の油学分踓 \\
\hline $\mathrm{C}_{4} \mathrm{H}_{9} \mathrm{OH}$ & $1: 10$ & $5 \mathrm{hrs}$ & $\begin{array}{l}15 \% \text { の油と } \\
\text { 㒕 }\end{array}$ & \%の水を分 & $1: 10$ & $5 \mathrm{hrs}$ & 50\%つ油を分離 \\
\hline $\mathrm{C} \mathrm{Cl}_{4}$ & & $3 \mathrm{hrs}$ & $\begin{array}{l}\text { 深加量如何k } \\
\text { の油を浮上ᄂ }\end{array}$ & $\begin{array}{l}\text { 贸はらす微量 } \\
\text { 下部㠜固 }\end{array}$ & & $3 \mathrm{hrs}$ & $\begin{array}{l}\text { 量の如何に關ら } \\
\text { ず效最なし }\end{array}$ \\
\hline $\mathrm{CHCl}_{3}$ & & $3 \mathrm{hrs}$ & 同 上 & & 1 & $3 \mathrm{hrs}$ & 同上 \\
\hline ガソリン & $1: 6$ & $3 \mathrm{hrs}$ & 12\%の油を & & $1: 10$ & $5 \mathrm{hrs}$ & 15\%の油, $30 \%$ \\
\hline
\end{tabular}

此の結果に於ては，その代表的なものについて例を示したに過ぎないが,還 心分離器等に俵万機械的な分離の結果と大した相違を示さない。即ち機械的 な破壞法に依ろ油水分離の難易の順序には何等の變化を示さないのである。 此所に於て吾々は次表に示す如き覒種の無機薬品を少量宛加へることに依 つて．前逊した難易の順序の敩化を期待した。

第3 表 無機薬品に依る原油エマ゙ルジョンの分離狀態

\begin{tabular}{|c|c|c|c|c|c|c|c|}
\hline 誈 料 & \multicolumn{2}{|c|}{ 新 } & 發 & 田 & \multicolumn{3}{|c|}{ 小 } \\
\hline 添加裙 & 添加量 & 加溫 & 分 離 & 狀 態 & 添加量 & 加溫 & 分離狀態 \\
\hline $\begin{array}{l}\text { Cone, } \\
\mathrm{H}_{2} \mathrm{SO}_{4}\end{array}$ & $1: 10$ & & 直ちに漖固 & & $1: 10$ & $5 \mathrm{hrs}$ & $25 \%$ 眖水 \\
\hline $\begin{array}{l}\mathrm{1-N} \\
\mathrm{NaOH}\end{array}$ & $1: 10$ & $3 \mathrm{hrs}$ & 砂及び20\% & 油を分離 & $1: 10$ & $5 \mathrm{hrs}$ & $\mid \begin{array}{l}\text { 作用なし } \\
5 \mathrm{C} \% \text { の油を分離 }\end{array}$ \\
\hline $\begin{array}{l}0.1-\mathrm{N} \\
\mathrm{NaOH}\end{array}$ & $1: 10$ & $3 \mathrm{hrs}$ & $\begin{array}{l}\text { 微量の油を } \\
\text { 少凝固 }\end{array}$ & 離，放置せ & $1: 10$ & $\begin{array}{l}5 \mathrm{hrs} \\
8 \mathrm{hrs}\end{array}$ & 同 上 \\
\hline $\begin{array}{r}10 \% \\
\mathrm{CaCl}_{2} \\
\end{array}$ & $1: 10$ & $4 \mathrm{hrs}$ & $\begin{array}{l}30 \% \text { の油を } \\
\text { 凝固 }\end{array}$ & 雜放置せば & $1: 15$ & $4 \mathrm{hrs}$ & $\begin{array}{l}\text { 徽㽣油浮上, 下 } \\
\end{array}$ \\
\hline $\begin{array}{c}10 \% \\
\mathrm{KrCO}_{3}\end{array}$ & $1: 10$ & $2 \mathrm{hrs}$ & $28 \%$ の酒を & & $1: 12$ & $2 \mathrm{hrs}$ & $25 \%$ \\
\hline
\end{tabular}




\begin{tabular}{|c|c|c|c|c|c|}
\hline $\mathrm{Fe} \mathrm{Cl}_{3}$ & 㬐昷 & & 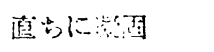 & $1: 10$ & 作用なし \\
\hline $\begin{array}{c}1 \% \\
\mathrm{Na}_{2} \mathrm{CO}\end{array}$ & $1: 10$ & $4 \mathrm{hrs}$ & 30\%0泊を分旗 & \multirow{3}{*}{\multicolumn{2}{|c|}{ 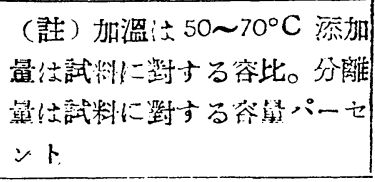 }} \\
\hline $\begin{array}{c}10 \% \\
\mathrm{Na}_{2} \mathrm{CO}_{3} \\
\end{array}$ & $1: 10$ & $4 h i s$ & 16\%の油を分﨎 & & \\
\hline 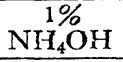 & $1: 16$ & $4 \mathrm{hrs}$ & 33\%の油を分㒕 & & \\
\hline
\end{tabular}

此の場合に、漱留田エマルジョンの如き比䩙的分離し易い試料に對して, $\mathrm{NaO}_{4}^{-1}, \mathrm{Na}_{2} \mathrm{CO}_{3}, \mathrm{~K}_{2} \mathrm{Co}_{3}, \mathrm{NH}_{4} \mathrm{OH}$ の如さテルカリ性を示す藥品の少量の添 加が著しく有效に作用する。反之中性或は酸性䓠是する薬品の添加は殆んよ゙ 何の效果も示して居ない。

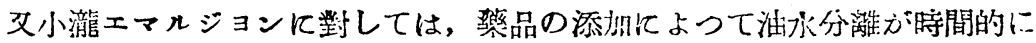

第4 表 各㴟度 $\mathrm{NaOH}$ 亿依る新發 田エマルジョン分離狀態

\begin{tabular}{|c|c|c|}
\hline 甄 度: & 添加量 & 分 離 狀 態 \\
\hline $0.01 \mathrm{~N}$ & 1. 10 & 分雅せず \\
\hline $0.1 \mathrm{~N}$ & " & $" 1$ \\
\hline 0. $5 \mathrm{~N}$ & II & 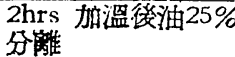 \\
\hline 1. $0 \mathrm{~N}$ & "I & $\begin{array}{l}2 \mathrm{hrs} \text { 扣溫放油 } 6.4 \% \\
\text { 分離 }\end{array}$ \\
\hline \multicolumn{3}{|c|}{ （註）添加量，分離鳃前表に同じ } \\
\hline
\end{tabular}

第 5 表 $0.5 \mathrm{~N} \mathrm{NaOH}$ に依る新發 田エマルジョン分離狀態

\begin{tabular}{|c|c|c|}
\hline 添加富 & $\mathrm{NaOH}$ 量 & 油分離 狀態 \\
\hline $15 / 100$ & $0.3 \mathrm{~g} / 1$ & $0 \%$ \\
\hline $3_{100}^{\prime}$ & 0.6 & 6.5 \\
\hline $5 ! 100$ & 1.0 & 28.0 \\
\hline $7: 100$ & 1.4 & 26.0 \\
\hline $10 / 100$ & 2.0 & 7.0 \\
\hline $201_{00}$ & 4.0 & 7.0 \\
\hline \multicolumn{3}{|c|}{ 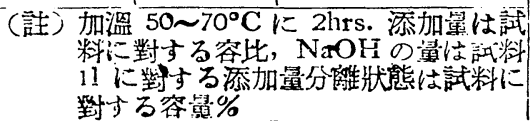 } \\
\hline
\end{tabular}

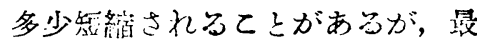
後们結啉仁於て，加熱或は遠心分

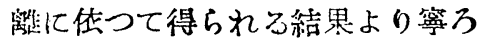

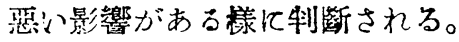
此等门異筫は影初に示した冬地 エマルジョンり䘤心分離の結果ひ

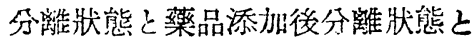
の比䎧に位つて明かに知ることが 出來方。處が此の無機藥品添加が 好結果を辫らす新發出エマルジョ ンに對しても有效藥品の通剩们却 つて惡效果を窗らすことが知られ たので，(第 3 表參照)更に苛性ソ ーダの各種濃度のもの学用ひて寔 驗を行つて見た。その結果は第 4 表及び第 5 表に見る如く，2 時間 程度り加瑥によつて分離枵熊を比 


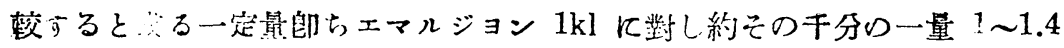
$\mathrm{kg}$ の奇性ソーダの等のみ䕐しく效果が汸つて，その限界を超えると效果が 著しく低下する。

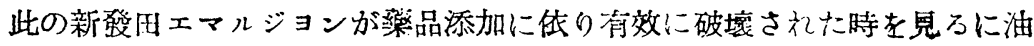
分の粘性は添加前後に餘り變化を示していないがその $\mathrm{PH}$ 值は變化して，

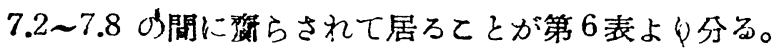

第 6 蓄 $0.5 \mathrm{~N} \mathrm{NaOH}$ 添加 に依る分䶆水のPH 及び粘性つ㢣化

\begin{tabular}{|c|c|c|}
\hline 添加谓 & 粘 性 & PH \\
\hline 0 & $0.86 \mathrm{C.P}$ & 6.55 \\
\hline $3 / 100$ & 0.89 & 7.45 \\
\hline 5/100 & 089 & 7.80 \\
\hline $7 / 100$ & 0.89 & 11.40 \\
\hline
\end{tabular}

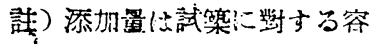
比。粘性は Ostwald 粘 度敦で測定
そこで筹者らは各地エマルジョンの含有 する水の $\mathrm{PH}$ 在測定して見たのであるが その結果比較的容易に分踓されろ小瀧，高 野等のエネルジョンの含有水のＰH は何 れる7.2〜7.8 に介在:る。此所飞吾々は エマルジョンの破壞に當つて教剫されねば ならぬ要素は色ね舉訬られるであらうが， この $\mathrm{PH}$ 值が 7.2 7.8 に存在すること もその中の善要な要素の一つとして着目さ ねばなら婷に氣附くのである。

〔3]以上の事窗は更飞次の如き實驗に於いても芝持される。即ち初到に 珯種のスルフオン酸及びその監が破壞梁として有效である事を郡したが。吾

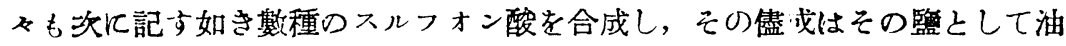
水分離作用を检べた。その結果は何れも微アルカリ性にェマルジョンを留ら するのか效果を表はして居る。郎ちとマシ油，トルオール，ナフタレン等の スルフォン酸及び油溶性石油スルフオ二酸（マホガニーソープ）等の作用を

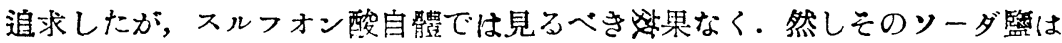
有效な分離作用を呈しけ。又此所に興味ある事富はナフタレンスルフォン酸 ソーダの $a$ 型 $(\overbrace{}^{\mathrm{SO}^{\mathrm{Na}}})$ 及で $\beta$ 型 $\left(\left(^{\mathrm{SO}^{\mathrm{Na}}}\right)\right.$ の兩者は, この棈造が類

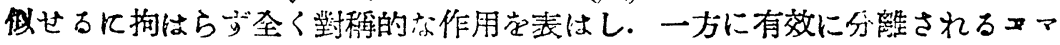
ルジョンは他方に全く働かれない。例へば 


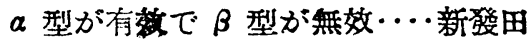

\section{$\beta \quad \alpha$ " $\quad$ " $\cdots$ 雄物川, 八㷊}

此の事も兩型のアルカリ度の相異に基づくものと思はれる。

依つて破垻制としての一つの保件はエマルジョンの $\mathrm{PH}$ を $7.2 \sim 7.8$ に齊 らす如き性質と量が必要であつて，その狀態に至つて後に，界面張力の變化 を來してその任称を果すものと理解されるのである。スェマルジョンの構成

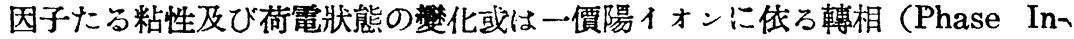
version）等の保件が必要とされるにしても，夫等も同じく一方に $\mathrm{PH}$ ，存 7.2〜7.8に者らしつつその效果を現はじて居るのでないだらうか。

上述の推訜を支持する第二の事筫が次囷に於て示される。郎ち新發田エマ ルジョンに對して PH の異なる藥品を添加せる場合の裳心分離時間と分離 战熊を示せるものが第 1 圆であろが此所でも最良の狀態郎ち PH 7.2〜7.8 にもたらす $\mathrm{NaOH}$ 、が最も有効である。

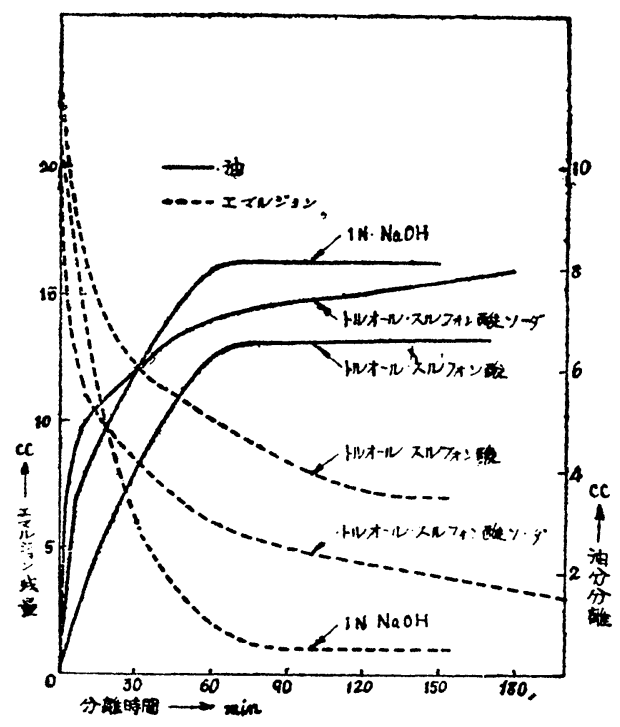

筑 1 圆 添加初の $\mathrm{PH}$ と分離時間の閶倸

第三の專曘として、吾なは 薬品に依ろエマルジョン破懐 凡關する研究々同時飞，高風 波に依る油水分離をも研究中

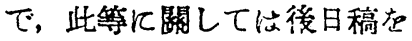
改めて報したいと思つて居 る。此の高周波の利用比於て b，その急速な加溫的效果湾 並行して，新たなる作用を認 めて居るのであるが，PH を $7.2 \sim 7.8$ にもらしてその作 用を利用する時，藥品の場合 と全く同時に或は一段そ效果 を發揮せしめる事を新發田エマルジョン其他で賽驗的に證明した。 
以上が現在迄に筆者管が得た結果の要約であるが，此の研究發表を快く䛨 可された帝石技衙研究所ね長星鐵三郎氏，並びに終始筆者らに葝切な指導を 與へられた藤井晴一博士に感謝の意を表するものである。

(1948年 1 月帝石技衔研究所化空)

\section{荟支献}

1. 上野幸作 -. 万石油の採掘」（共立社）428～431，(1941）

2. S. Bergmann \& G. Egloff: “Emulsions and Foams”, 338 371. (1941)

3. M. Gelbke : Ger. Pat. 595, 604 (1934) ; Chem. Abst., 1934, 28, 5271

4. H. Lemhurg : U. S. Pat. 1, 958, 680 (1934); Chem. Abst., $1934,28,4590$

5. L. Liberthon ; U. S. Pat. 1, 940, 870 (1.934); Chem, Abst., 1937, 28, 1526

6. D. S. Chambelain : Chem. Abst., 1937, 31, 1639

7. J. Sereda : Chem. Abst., 1934, 28, 913

8. M. De Groote : Chem. Abst., 1933, 27, 2029

9. D. N. Bukh : Chem. Abst., 1934, 23, 7492

10. C. Fisher : Chem. Abst., 1934, 28, 1849

11. E. M. Hugheo : U. S. Pat. 2, 056, 913 ; Chem. Abst., 1936, 30,8600

12. E. M. Hugheo : J. Inst. Pet Tech., 1936, 22, 501 A.

13. 14. J. C. Black : U. S. Pat. 1, 704, 588., 1928

15. Ayres : Ind. Eng. Chem., 13, 1921

16. 帝石生產報告 I001 號：「輕舞乳化原油の處理に就て」

17. Eliis, R. : Z. Physik, Chem., 89, 145 150, 1914

18. Powis: J. Chem. Soc., 108, 137, 1915

19. Steik : Am. Destuff Repts., 25, 429 435, 1936

20. loc. at. 